\title{
IMMIGRATION POLICY AND IDENTIFICATION ACROSS BORDERS
}

\author{
Matthew Lindauer
}

$\prod$

MMIGRATION POLICIES can express disrespect for members of society, nonmembers, or both. Proponents of the traditional state sovereignty view on immigration have generally held that only policies in the first and third categories could be moral wrongs - it is morally regrettable, perhaps, but not morally impermissible for a state to implement immigration policies that express disrespect for outsiders.

One problem with the state sovereignty view, I argue, is that it is insensitive to the ways in which members and nonmembers relate to one another. The "external relationships" of members, relationships they stand in with nonmembers, make it the case that the treatment of nonmembers can affect or express attitudes about members themselves. Some of these relationships are what we might call "relationships of closeness," such as family and romantic relationships. In this paper, I focus instead on "relationships of likeness," or more specifically, relationships between members and nonmembers that hold due to a shared quality or set of qualities on the basis of which members identify with nonmembers. These relationships of likeness make it the case that immigration policies that discriminate against nonmembers also often discriminate against members, and while this point has been recognized to some extent, its full implications have not been appreciated.

Some theorists who defend the state sovereignty view, in fact, have tried to curtail the permissive implications of the view for policies that are racially, ethnically, or otherwise discriminatory by appealing to discrimination against members. One argument of this kind that Christopher Heath Wellman has used to defend the state sovereignty view was originally given by Michael Blake. ${ }^{1}$ Blake argues that, because immigration policies that discriminate against nonmem-

1 Blake, "Immigration," 233-34. See Wellman, "Immigration and Freedom of Association," 139-41. For different critical responses to Wellman, see Fine, "Freedom of Association Is Not the Answer"; Blake, "Immigration, Association, and Antidiscrimination"; Cavallero, "Association and Asylum"; and Wilcox, "Do Duties to Outsiders Entail Open Borders?" 
bers typically also make invidious comparisons between members, discriminatory immigration policies can be morally impermissible even by the lights of the state sovereignty view. Blake did not intend for this argument to undermine the state sovereignty view, nor did Wellman think it did. However, I argue that the fact that states generally cannot implement discriminatory immigration policies without expressing disrespect for their own members, contra Blake and Wellman, is a serious problem for the state sovereignty view.

As Wellman acknowledges in later work, Blake's argument may be unsatisfying for at least two reasons. ${ }^{2}$ First, it seems odd to think that the White Australia policy, the Chinese Exclusion Act, and Donald Trump's recent executive orders on immigration have only been wrong in virtue of discriminating against insiders. Second, the argument is silent about the use of discriminatory immigration policies when the groups that these policies discriminate against are not already present. If there are no people of Mexican descent in a given society, that society can discriminate against Mexicans seeking admission, for all the argument says. For these reasons, Wellman states that, while he is most drawn to this strategy for explaining why discriminatory immigration policies are morally wrong, he is not fully satisfied with it. ${ }^{3}$

In this paper, I argue that the domestic implications of discriminatory immigration policies are far-reaching and undermine, rather than support, the state sovereignty view. Once we grasp the full extent to which immigration policies are constrained by the principle of equal respect for members, a principle that contemporary forms of the view are committed to, we will see that the view cannot hold on to one of its main distinguishing features - the wide latitude it ascribes to societies in determining and implementing their immigration policies. On considerations of domestic justice alone, my argument shows that the state sovereignty view cannot serve as a satisfactory framework for the normative assessment of immigration policies. Notably, this argument differs from those offered by critics of the view that favor open borders, who have often challenged its partiality toward members. This article also gives a unified explanation of how historical and hypothetical immigration policies discussed in the ethics of immigration literature could express disrespect for members of society. This explanation draws on the existence of the external relationships of members that are grounded in identification with nonmembers on the basis of a shared quality or set of qualities. ${ }^{4}$ In conclusion, I suggest that the existence of these external

2 Cole and Wellman, Debating the Ethics of Immigration.

3 Cole and Wellman, Debating the Ethics of Immigration, 150.

4 The title of this article may be taken to suggest that nonmembers will always be "across borders" from members, or outside of the polity. In actuality, of course, societies often contain 
relationships has additional implications for the ethics of immigration that have yet to be fully explored, and that examining this terrain will be essential in developing a fully satisfactory framework for the normative assessment of immigration policies.

\section{THE STATE SOVEREIGNTY VIEW}

The state sovereignty view regarding immigration policy accords a great deal of latitude to societies to exclude or give less than equal treatment to some nonmembers who wish to enter and become full members. In this paper, I at times refer to these kinds of policies as "discriminatory" immigration policies, since they involve discrimination against certain nonmembers. I will not discuss restrictive immigration policies that would not, at least in any obvious way, discriminate against a particular group of immigrants, such as a policy of excluding all potential newcomers, or a policy of capping immigration at a desired number. The view that I am concerned with here is committed to the sovereignty of states to determine immigration policies as they see fit, with very few exceptions. This view continues to be endorsed by prominent theorists working on the ethics of immigration and border control..$^{5}$ As we will see, state sovereignty has been thought to entail the moral discretion of states to discriminate against immigrants on the basis of features such as race and ethnicity.

Two of the most prominent contemporary defenses of the state sovereignty view are due to Michael Walzer and Christopher Heath Wellman. ${ }^{6}$ According to both theorists, members of society, understood as a political entity or state, are given priority in the determination of that society's immigration policies. Wal-

people who are not full members, such as temporary migrants. For the purposes of this paper, my focus is on nonmembers who are not yet present within a society and policies concerning whether they will be admitted and given membership. There are many interesting questions pertaining to how societies should respond to people who are already present within their borders but who are not full members; I cannot address them all here. I also refer to members and nonmembers throughout the paper, rather than citizens and noncitizens, for ease of exposition. These two categories are treated, for my purposes, as mutually exclusive and exhaustive, and nothing in my argument turns on the existence of other categories of membership that fall between them.

5 My argument does not conclude that it is morally impermissible for states to restrict immigration in general. More moderate views that justify only a highly circumscribed right to restrict immigration are not my target here. For three such views, see Miller, "Immigrants, Nations, and Citizenship"; Pevnick, Immigration and the Constraints of Justice; and Blake, "Immigration, Jurisdiction, and Exclusion."

6 For one of the earliest philosophical attempts to defend the state sovereignty view, see Sidgwick, The Elements of Politics. 
zer's piece on immigration policy is the locus classicus of the state sovereignty view in the ethics of immigration literature. ${ }^{7} \mathrm{He}$ argues that if we think that individuals have a right to form self-determining societies we must believe that the members of these societies have a collective right to control and restrain the influx of immigrants. The right of a society to determine its own immigration policy, in other words, is necessary for the sovereignty and security of that society as a distinct political community. Admission and exclusion "suggest the deepest meaning of self-determination." All else being equal, then, a society is permitted to implement discriminatory immigration policies. According to Walzer, as long as Australia gave up some of its unused territory to persons seeking to set up a society where non-whites could enter and become members, the White Australia policy would have been morally permissible to keep in place. This was a policy of excluding non-whites as candidates for immigration to Australia, instituted at the time of Australian federation in 1901 and gradually dismantled between 1949 and 1973. Walzer does not commend White Australia, of course, but believes that "White Australia could survive only as Little Australia." Morally regrettable as it might have been, this racially discriminatory immigration policy did not in itself wrong anyone. For Walzer, societies do have to take in at least some refugees and perhaps certain family members of insiders, but policies that discriminate against immigrants on the basis of race or ethnicity are not morally wrong per se. ${ }^{10}$

Wellman has recently offered a prominent defense of the state sovereignty view on grounds of freedom of association. ${ }^{11} \mathrm{He}$ also emphasizes the rights of individuals to form self-determining societies, but his argument centers on freedom of association as an integral component of self-determination. As in the case of individuals, a society's freedom of association entitles it to associate or not associate with persons as it sees fit. Legitimate societies, ones that respect the human rights of their constituents and all other persons, are entitled to self-determination and hence freedom of association for Wellman. Taking seriously freedom of association at the level of societies entails that societies are entitled to wide latitude in setting and administering their immigration policies. In contrast with Walzer, Wellman holds that a state is not required to admit

Walzer, Spheres of Justice, ch. 2.

8 Walzer, Spheres of Justice, 62.

9 Walzer, Spheres of Justice, 47.

10 Walzer, Spheres of Justice, 48-51.

11 Wellman, "Immigration and Freedom of Association"; Cole and Wellman, Debating the Ethics of Immigration. 
refugees so long as there are other ways of helping them. ${ }^{12}$ He regards family members and romantic partners of insiders as perhaps the only exception to the nearly unqualified right to exclude. ${ }^{13}$ Most importantly for my purposes, as I noted above, he is inclined toward Blake's insider-focused explanation of why discriminatory immigration policies are morally wrong, but not fully satisfied that this explanation works.

As I noted above, both defenses of the state sovereignty view ultimately rely on the rights of members as the source of a society's prerogatives to discriminate against immigrants. ${ }^{14}$ The rights of members to form and maintain self-determining societies generally trump any rights that nonmembers might have to enter or receive equal treatment. We should also note that both defenses are intended to work within liberal egalitarian political theory, which is committed to the equality of members of society. ${ }^{15}$ Walzer and Wellman deny that, as critics have asserted, the rights of nonmembers limit the moral discretion of societies in determining their immigration policies. ${ }^{16} \mathrm{I}$ will avoid this impasse regarding the relative weight of the rights of members and nonmembers in matters of immigration policy. I will instead grant Walzer and Wellman the premise that the rights of members trump the rights of nonmembers for the sake of argument, and argue that a core principle of liberal egalitarianism, the principle of equal respect for members, is part of the explanation of a deep internal problem with the state sovereignty view. The argument relies only on grounds of domestic justice, and concludes that even granting this premise, it can be demonstrated that the view is not a satisfactory framework for the normative assessment of immigration policies.

Wellman, "Immigration and Freedom of Association," 109-41; Cole and Wellman, Debating the Ethics of Immigration, 117-24.

Cole and Wellman, Debating the Ethics of Immigration, 92.

14

David Miller also defends a state's sovereignty regarding immigration in general. However Miller regards it as unjust to discriminate against immigrants on the basis of race or ethnicity, although he denies that there is a human right against such treatment. See Miller, "Border Regimes and Human Rights," 19.

15 On Walzer's liberal credentials, it is worth noting that he regards his criticisms of certain liberal theories of justice, sometimes referred to as "communitarian" objections (Walzer has sought to distance himself from this label), as being "available for incorporation within liberal (or social democratic) politics." See Walzer, Thinking Politically, 97. In Spheres of Justice, Walzer offers a social democratic model of justice that, as we see from the above quotation, he does not regard as at odds with liberalism. Even if we leave these points aside, his view is also meant to apply to the immigration policies of liberal societies.

16 See, e.g., Carens, "Aliens and Citizens: The Case for Open Borders"; Abizadeh, "Democratic Theory and Border Coercion: No Right to Unilaterally Control Your Own Borders." 


\section{EXTERNAL RELATIONSHIPS AND IDENTIFICATION WITH NONMEMBERS}

I will use the term "external relationship" to capture the notion of a morally significant relationship that exists between at least one member of a society and at least one nonmember. For my purposes, it will suffice to characterize a relationship as a tie or connection between two or more parties that exists due to a quality or qualities that some or all of these parties possess. External relationships, then, are ties or connections between members and nonmembers that exist due to qualities that they possess and that are morally significant. Some members of modern democratic societies participate in relationships with nonmembersthey are tied to or connected with these nonmembers - in virtue of accepting shared cultural or religious norms. For instance, many Mexican-Americans identify with Mexican nationals on the basis of treating shared cultural experiences and history as valuable, and many Jewish-Americans take themselves to have a special tie to the Israeli people on the basis of valuing a shared ethnic and religious tradition. These relationships have wholly domestic analogues; there are similar kinds of relationships in which the parties are all members of the same society. We can think of these other wholly domestic relationships as "internal relationships."

The kinds of external relationships that I focus on here, like the ones mentioned above, are relationships with nonmembers that members seek to enter or remain in. Further, this paper only addresses external relationships that members seek to enter or remain in that involve identification with nonmembers. Other kinds of external relationships exist, and some are clearly morally significant. In particular, I have in mind what I referred to above as "relationships of closeness," including family relationships, romantic relationships, friendships, and perhaps other forms of partnership. ${ }^{17}$ Because Walzer and Wellman are both willing to make concessions for certain relationships of closeness, I focus in this article instead on relationships of likeness, and in particular external relationships that involve identification with nonmembers.

My thought is that a member's sense that they themselves are being respected,

17 These external relationships also constrain a society's immigration policies by giving rise to demands of domestic justice. See Matthew Lister's discussions of the importance of family reunification ("Immigration, Association, and the Family") and the demands of equality for same-sex couples seeking marriage-based admissions ("A Rawlsian Argument for Extending Family-Based Immigration Benefits to Same-Sex Couples"). See also Luara Ferracioli's argument that liberal societies must extend similar immigration benefits to friends and creative partners of members if they extend them to family members and spouses ("Family Migration Schemes and Liberal Neutrality: A Dilemma"). Examining the case for these arguments is beyond the scope of the present paper. 
disrespected, helped, or harmed can depend in part on how nonmembers whom they identify with are being treated. Identification of this kind involves seeing oneself as sharing a quality with other people such that when they are treated in a certain way on the basis of possessing this quality this treatment is taken to express certain attitudes about oneself. For instance, if John is a Catholic and a shop is known to have a policy of refusing to hire Catholics, John may regard the policy as a personal affront, even if he has no intention of seeking employment at the shop. The shop's policy is most naturally interpreted as expressing the attitude that Catholics in particular are not wanted around the shop and John, in identifying with other Catholics, would justifiably feel that the policy expressed disrespect for him for this reason.

To be sure, there are senses of "identifying with" others that may not give rise to this sort of indirect expression of attitudes. Anne may be a Protestant who identifies with the Catholics who are being discriminated against by the shop's employment policy in the sense that she sees their struggle as one that she is personally invested in. Nonetheless, the shop's policy does not express disrespect for Anne, or at least not in the same way that it expresses disrespect for John. To give a rough characterization, two conditions are jointly sufficient for the treatment of others to potentially express attitudes about oneself. First, there is identification as possessing a certain quality possessed by the other person or persons, and second, there is identification with the other person or persons on the basis of their possessing this quality. ${ }^{18}$ Both conditions are factive with respect to the possession of the quality on the basis of which other persons are being discriminated against. In the example just given, John identifies as a Catholic and also identifies with other Catholics on the basis of this fact. Anne, by contrast, does not identify as a Catholic, and cannot be said to identify with Catholics except in an attenuated sense of the term. My claim is that when both conditions obtain for a person, all else being equal, discrimination against other persons on the basis of the relevant quality will also express disrespect for that person. For ease of exposition, I will refer to this way of relating to others as "identifying with" them. It is this sense of the term that more plausibly captures the notion of group iden-

18 This is compatible, of course, with discrimination toward insiders being a result of discrimination toward outsiders even in cases in which insiders do not identify as members of the targeted group. My claim is not that either identification as or identification with are necessary conditions for the occurrence of indirect discrimination of this kind. In cases such as that of one of the plaintiffs in Romer, a person may be discriminated against for a quality that they are thought by others to possess (i.e., being gay) even when they do not in fact possess that quality. Romer v. Evans, 517 U.S. 620 (1996). There is no reason why immigration laws could not similarly target some members of society who are merely thought to possess a given quality. I am grateful to an anonymous reviewer for urging me to clarify this point. 
tification, even if we should allow that there are other senses of identifying with others that do not involve identification as sharing the same quality or qualities nor identification with them on this basis. ${ }^{19}$

The phenomenon of identifying with others helps explain why statements of the form "I regard you as an exception, a good one" when the speaker is addressing a member of some group that the speaker has a prejudice against are rarely comforting to the addressee. The fact of not being the direct object of discrimination does not cancel the fact that discrimination against other members of one's group expresses disrespect for oneself when one identifies with them. Additionally, while these two conditions are jointly sufficient for indirect expressive disrespect of the kind just discussed to be possible, discrimination against others who share a quality that one possesses may precipitate identifying with these other persons, or doing so more strongly. There are many interesting questions that one can take up regarding these notions that I do not have the space to engage at length here. I will focus on cases in which identification with others is relatively stable and, as noted earlier, the relationship of identification with nonmembers already exists. Before giving my argument in more detail, I must first say a bit more about how I am understanding respect and disrespect in this context.

\section{THE PRINCIPLE OF EQUAL RESPECT FOR MEMBERS}

The principle of equal respect for members is a core principle of liberal egalitarianism, and gives rise to important demands of domestic justice. ${ }^{20}$ I will not try to say too much in defense of the principle or any particular version of liberalism. But I will say a bit to specify how I understand the principle. In doing so, I am not committed to the view that other, slightly different versions of the principle would not work equally well for my purposes. The principle is a central commitment of liberal egalitarianism but admits of different specifications. Any plausible version or interpretation of the principle will rule out discriminatory immigration policies as expressing disrespect for members in instances where members are also discriminated against by the policies.

19 On the identification-based elements of group membership, see, e.g., Appiah, The Ethics of Identity, and Kymlicka, Multicultural Citizenship.

Elizabeth Anderson holds that expressing equal respect and concern for all citizens is "the most fundamental test any egalitarian theory must meet" ("What Is the Point of Equality?" 289). Ronald Dworkin also argues that a right to equal concern and respect is the most fundamental right of persons. See Dworkin, Taking Rights Seriously. I focus in this paper on equal respect. It is an open question what further conditions on immigration policies the requirements of equal concern could justify. 
The principle of equal respect for members holds that society's political institutions, policies, and members in their official capacities must treat all members of society with equal respect and, when applicable, must express equal respect for them. I tend to view these requirements in terms of recognition respect. ${ }^{21}$ Respecting or expressing respect for someone in this sense requires giving appropriate consideration or recognition to the fact that they are a person and constraining one's conduct in ways that are morally required by this fact. ${ }^{22}$ What this concretely entails will depend on the particular actions or policies at issue and the circumstances in which they are executed. In this article, I focus primarily on immigration policies and their expressive significance, the attitudes that the policies are most naturally interpreted as expressing about members. Immigration policies can express attitudes not only about potential immigrants: that they are wanted or not wanted by the society, that they are on par with others seeking to enter or less valued, to take some examples. They can also express similar attitudes about members of society when members identify with nonmembers on the basis of qualities that they share and these qualities are picked out for discriminatory treatment by the policies.

If equal respect for members is indeed an important principle of liberal egalitarianism, it follows that proponents of the state sovereignty view, strictly speaking, have two choices. One is to give up their commitment to this principle, endangering the liberal credentials of their view. The other is to show that my argument can be answered. The second option is the obvious one for any liberal theorist to take, but it is worth flagging what is at stake in considering the first option. Because I do not regard the first option as viable for contemporary proponents of the state sovereignty view, who claim that their view is consistent with liberal principles, I will not discuss it further.

\section{IDENTIFICATION WITH NONMEMBERS AND EQUAL RESPECT FOR MEMBERS}

With this theoretical background in place, we can demonstrate the significance of external relationships in which members identify with nonmembers for the normative assessment of immigration policies. Walzer and Wellman defend the state sovereignty view and rely on the premise that the rights of members ultimately justify the wide latitude that the view attributes to societies over how they treat nonmembers seeking entrance. Yet appeal to the standing of members as political equals supports a powerful argument against discriminatory immi-

The distinction between recognition respect and appraisal respect is due to Stephen Darwall. See Darwall, “Two Kinds of Respect.”

Darwall, "Two Kinds of Respect," 45. 
gration policies to an extent that renders the state sovereignty view untenable. Immigration policies that would discriminate against certain nonmembers on the basis of their race, ethnicity, nationality, religion, gender, gender identity, sexual orientation, or disability can be morally impermissible to implement on grounds of domestic justice alone. This will be the case when members of society identify with these nonmembers on the basis of the criteria that the policy would use to discriminate against the nonmembers.

First, we consider policies of outright exclusion on the basis of these criteria. We can imagine a society in which 80 percent of the population wishes to implement a policy of refusing entrance for a certain group of nonmembers, picked out for their race, ethnicity, nationality, religion, gender, gender identity, sexual orientation, or disability. On the other hand, 20 percent of the population is composed of members who identify with and are known to identify with these nonmembers on the basis of sharing the quality that they would be excluded for possessing if the policy were implemented. ${ }^{23}$ Even if we bracket the claims of the nonmembers in this case for the sake of argument, it would still be impermissible for the majority to impose the policy of refusing entrance for this group of nonmembers, all else being equal. The principle of equal respect for members justifies this judgment. The policy proposal is most naturally interpreted as expressing the attitude that nonmembers in this group are not wanted as potential members of society, and additionally that members who identify with them are not valued as members of society. This second attitude, the one that is directly relevant as a matter of domestic justice, expresses disrespect for members, violating the expressive requirement of the principle of equal respect for members.

In slightly different terms, policies of outright exclusion can express attitudes about persons who constitute a distinct group or a "we" that members of society also see themselves as part of. To paraphrase Michael Dummett's critical encapsulation, "keep them out, but treat them decently if they are already here" 24 is a discriminatory attitude regarding a group or a "we" consisting both of persons to be kept out, nonmembers, and persons who are already present in society, members in this case. Discrimination against members or "negative discrimination" within a society is morally impermissible, and the principle of equal respect for members justifies this judgment. Policies of outright exclusion can therefore be

23 Of course, these percentages are implausible for some of these qualities in most actual societies, but the point that I am making is not affected by this fact.

24 Dummett's phrase is "keep them out, but treat them decently if they do get in." See Dummett, On Immigration and Refugees, 111. Dummett is here discussing what he refers to as the "familiar principle" behind the second Race Relations Act passed by the United Kingdom's Parliament in 1976. 
impermissible to implement on grounds of domestic justice. The implication that members' presence in society is regrettable and that if only they were not already present they should be refused just like the others with whom they identify is deeply disrespectful of them.

External relationships significantly limit the moral discretion that societies have over their immigration policies, then, on grounds that even proponents of the state sovereignty view are committed to. The relationships that I have focused on involve identification with nonmembers on the basis of sharing the same race, ethnicity, nationality, religion, gender, gender identity, sexual orientation, or disability. To exclude nonmembers based on these qualities is also to express disrespect for members who possess them.

What about policies that would give preferential treatment to certain nonmembers? Considering policies of outright exclusion may help us to see that immigration policy is constrained by the principle of equal respect for members most clearly. However, it is important to establish that a similar line of argument shows that external relationships grounded in identification and the principle of equal respect for members also render "positive discrimination," discrimination in favor of certain immigrants over others, impermissible in many cases. To use a case that parallels the previous one involving a policy of outright exclusion, imagine that an 80 percent majority aims to implement an immigration policy that would give preferential treatment to nonmembers whom they identify with and are known to identify with. However, a 20 percent minority identifies with and is known to identify with another group of nonmembers. The policy that the majority seeks to implement in this case, all else being equal, would also violate the principle of equal respect for members. Drawing on the previous discussion, the expression of an attitude regarding certain nonmembers coincides with the expression of an attitude about members who identify with and are known to identify with them. By expressing the attitude that certain nonmembers are the kinds of persons that the society wishes to admit more of than others, the policy also expresses the attitude that the members who identify with the preferred nonmembers are more valuable members of society. "We should have more members like us than members like you" is naturally interpreted by the minority as the kind of attitude behind the policy being proposed by the majority. Positive discrimination in this case also implies a negative comparative judgment about the value of members of society in the minority.

I have again deliberately left the basis on which members identify with particular groups of nonmembers open in this case. As suggested earlier, identification on the basis of sharing the same race, ethnicity, nationality, religion, gender, gender identity, sexual orientation, or disability gives rise to possible violations 
of the principle of equal respect for members by immigration policies. Of course, there are likely to be important differences between these criteria in terms of the expressive significance of their use in immigration policies. Yet policies that would employ these criteria as reasons for excluding or giving less than equal treatment to nonmembers share the important feature of potentially violating the principle of equal respect for members. If we accept the principle of equal respect for members, we recognize that societies have a duty not to implement policies that express disrespect for members. Policies of giving less than equal treatment to certain nonmembers can express the attitude that some members of society are more or less valuable than others as members.

The state sovereignty view, then, contains a deep inconsistency, at least in its contemporary forms. The justification for the wide latitude over immigration policy that it attributes to societies purports to rest on giving members their due morally. Yet even if we grant for the sake of argument that the rights of members generally trump the rights of nonmembers in matters of immigration policy, we should deny the claim that societies have wide latitude in this policy area. Indeed, societies are greatly morally constrained when setting their immigration policies by the requirements of the principle of equal respect for members. I have argued, in particular, that societies may not discriminate against nonmembers-exclude them or give them less than equal treatment-on the basis of their race, ethnicity, nationality, religion, gender, gender identity, sexual orientation, or disability when doing so would express disrespect for persons who are already members of society. Given the racial, ethnic, national origin, and religious diversity in modern democracies, and the presence of gender diversity, trans people, sexual minorities, and disabled persons in every society, these moral reasons nearly always come into play. Notably, they are reasons that proponents of the state sovereignty view are committed to recognizing in general, and they undermine the commitment that makes the view distinctive. If societies do not have the moral discretion to exclude or give less than equal treatment on the basis of this range of criteria, they are greatly constrained by the demands of morality in setting their immigration policies. Of course, for those of us who are not committed to the state sovereignty view, these may seem to be merely additional reasons against discriminatory immigration policies. Yet it is important to recognize that the state sovereignty view can be shown to be an unsatisfactory framework for the normative assessment of immigration policies from within, by an argument that meets its proponents on their own terms. Additionally, I will suggest that the focus on external relationships and the principle of equal respect for members has implications that are of independent interest beyond this internal critique of the state sovereignty view. 


\section{OBJECTIONS AND REPLIES}

I will now consider and respond to some of the objections to my argument that are likely to be raised. Along the way, I will also discuss the scope of the argument and some of the considerations that can render exclusion or less than equal treatment of certain nonmembers permissible. Lastly, I will discuss some of the implications that external relationships and the principle of equal respect for members have for the permissibility of immigration policies independently of the argument against the state sovereignty view.

As mentioned earlier, Wellman generally regards attempts to respond to cases of outright exclusion by appealing to the demands of domestic justice as helpful to the state sovereignty view. ${ }^{25}$ However, he has also raised objections to such attempts and stated that he is not fully satisfied with them. ${ }^{26}$ The discussion in the ethics of immigration literature on whether policies of outright exclusion on the basis of race or ethnicity are morally permissible arose largely in response to Walzer's discussion of the White Australia policy. As mentioned earlier, Walzer holds that this policy of banning non-whites, however morally regrettable, was not morally impermissible to implement in itself. As long as Australia ceded any large areas of unused territory to persons seeking to establish a society that nonwhites could enter and become members of, non-whites could be excluded on the basis of their race or ethnicity. Responding to Walzer, Michael Blake was one of the first commentators to argue that, given the fact that Australia was not and is not an ethnically homogenous nation, the White Australia policy was morally problematic domestically. ${ }^{27}$ Blake holds that whenever "there are national or ethnic minorities - which is to say, the vast majority of actual cases - to restrict immigration for national or ethnic reasons is to make some citizens politically inferior to others." ${ }^{28}$ The goal of eliminating the presence of a group from society through selective immigration is insulting to members of that group already present in society, and thus morally problematic. Blake did not take this argument to undermine the state sovereignty view and Wellman at first accepted it as a way of accommodating the intuition that the White Australia policy was morally wrong. ${ }^{29}$ Notably, this shows that Wellman is not merely concerned to argue for the less interesting and ambitious claim that third parties in general should not coerce societies to adopt morally acceptable immigration policies,

25 Wellman, "Immigration and Freedom of Association," 139-41.

Cole and Wellman, Debating the Ethics of Immigration, 149-50.

Blake, "Immigration."

Blake, “Immigration," 233.

Wellman, "Immigration and Freedom of Association," 139-40. 
which even proponents of open borders can endorse. Rather, he is concerned with what is morally wrong, which is a distinct question from what can be prevented or punished by third parties. ${ }^{30}$ In later work, however, Wellman states that he does not find Blake's line of argument fully satisfactory because it "justifies too little and too much." ${ }^{31}$ I will explain and examine each of these charges separately. Because of the concerns that I have with Blake's argument and the fact that my argument is directed against the state sovereignty view rather than at defending it, I will respond to these objections on behalf of my own argument.

Wellman's objection that the argumentative approach of appealing to the demands of domestic justice "justifies too little" points to the fact that it focuses on existing members of society who belong in some way to the group to be excluded. In a state that is entirely devoid of members who are in the group, Wellman states that the argument does not deliver any verdict. ${ }^{32}$ What would be wrong, for instance, with an entirely homogenous white society explicitly excluding all prospective non-white immigrants? Given that most of us would find such a policy morally abhorrent, we would like to have a good argument for the view that racially or ethnically discriminatory policies would be morally impermissible to implement even for a racially or ethnically homogenous society. Yet it does not seem that this approach can provide us with an argument against them.

It is correct to point out that the scope of Blake's argument, if used to defend the state sovereignty view, is limited in important ways. If the goal is to show that immigration policies involving outright exclusion on the basis of race or ethnicity are morally impermissible in general, it cannot be met with Blake's argument. In fact, there are three related but distinct concerns along these lines. First, as Wellman points out, the argument does not establish that discriminatory immigration policies would be morally impermissible for a fully homogenous society to implement.

Second, even ethnically diverse societies would not be prohibited by the argument from discriminating against persons on the basis of race or ethnicity per se, so long as persons of the relevant races or ethnicities were not present within the society as members. Wellman's own endorsement of Blake's argument in his 2008 article had a similar tendency to overgeneralize, holding that "because no state is completely without minorities who would be disrespected by an immigration policy which invoked racial/ethnic/religious categories, no state may

30 For an interesting discussion of whether democratic societies could have a moral right to implement wrongful policies and institutions, see Barry and Øverland, "Do Democratic Societies Have a Right to Do Wrong?"

Cole and Wellman, Debating the Ethics of Immigration, 149. 
exclude potential immigrants on these types of criteria." ${ }^{33}$ It is true that no state is completely without minority groups, but false that any immigration policy invoking racial, ethnic, or religious criteria must use criteria that some members of society fall under.

A third concern, which also highlights the importance of identification with nonmembers, is that even if there are members of society who fall under criteria that an immigration policy uses to discriminate against nonmembers, that policy still may not express disrespect for them. For a variety of reasons, members may not take it as a sign of disrespect toward themselves if nonmembers are discriminated against on the basis of possessing a quality that they also possess. Perhaps the members in question have lived in the new society for some time, and have ceased to regard their ethnicity as an important part of their sense of self. To take a slightly different case, they may have left their prior society during a time of political upheaval, and now wish to distance themselves from other persons of the same ethnicity seeking to enter. Something else is required beyond the mere fact that members share some quality with nonmembers for the exclusion of nonmembers on the basis of this quality to express disrespect for members. This is a third reason why there may not be any members of society who are disrespected by a policy of exclusion on the basis of race or ethnicity. However, one important reason why such members might be present, and perhaps the paradigmatic reason, is if some of them are in external relationships involving identification with nonmembers. When members are in external relationships involving identification with nonmembers, discrimination against nonmembers on the basis of race, ethnicity, nationality, religion, gender, gender identity, sexual orientation, or disability can express disrespect for these members. ${ }^{34}$ In contrast to Blake's approach, the argumentative approach that I have offered here explains the mechanism by which core cases of discrimination toward outsiders in the form of immigration policies manage to also discriminate against insiders.

Notably, the goal of my argument is not to show that racially or ethnically discriminatory policies are always morally impermissible on grounds of domestic justice. I view these policies as morally impermissible in virtue of wronging

(1) ers unless members identify with nonmembers. For instance, if all the members of society who are in favor of a policy of exclusion intend for it to express disrespect for some members, the policy may do so even if these members do not themselves identify with nonmembers. It may be tempting to describe this as a case in which members are "identified with" nonmembers by fellow members but do not identify with them. Given my purposes in this paper, it suffices to flag the fact that these are distinct notions and that it is identification with nonmembers on the part of members that I am interested in. 
nonmembers in general, although this is the topic of a separate paper. My interest in the range of policies that considerations of domestic justice render morally impermissible stems instead from the fact that exclusion or less than equal treatment on the basis of race, ethnicity, nationality, religion, gender, gender identity, sexual orientation, or disability can be morally impermissible on grounds of domestic justice. This suffices to show that societies are greatly constrained by the demands of morality when setting their immigration policies, undermining the state sovereignty view's most significant distinguishing feature, the wide latitude that it attributes to societies in this policy area. While its scope is in a sense more limited, then, my argument points to much broader implications of recognizing the demands of domestic justice for immigration policy and constitutes a powerful internal critique of the state sovereignty view. For this reason, Wellman's "justifies too little" objection has no force against my argument, while this criticism does apply to Blake's argument as a way of defending the state sovereignty view. At this point, I will fully leave Blake's argument aside, having demonstrated the differences between it and my own.

Wellman also raises the objection that the argumentative approach of appealing to demands of domestic justice "justifies too much," in the sense that it commits us to regarding some morally permissible immigration policies as morally impermissible. He provides a hypothetical case involving Norway and persons of Pakistani descent living there that is supposed to bring out this judgment. ${ }^{35}$ Wellman has us imagine that Norwegians have a national discussion and collectively decide that while one hundred thousand more Pakistanis would be a welcome addition, no more than one hundred thousand should be allowed in. There is an imagined consensus that taking in more than one hundred thousand Pakistanis might give rise to difficult societal issues due to having a large national origin group with its own cultural practices and traditions present within the society's borders. Reflecting on this case, we are supposed to consider what should be done once one hundred thousand additional Pakistanis have entered Norway, and whether it would be permissible for the Norwegians to decide to prevent further immigration from Pakistan. Wellman states that he is not convinced that doing so would be unjust, even if many members of Norwegian society who had immigrated to Norway from Pakistan would be insulted, and understandably so, by the policy. He thinks that something must be wrong with an immigration policy that excludes prospective newcomers on the basis of their nationality. ${ }^{36}$ Yet he is not fully satisfied with the view that this type of immigration policy can 
be shown to be morally impermissible to implement by appealing to demands of domestic justice.

The hypothetical case on offer involves many factors and assumptions that make it hard to test what our intuitions regarding it tell us about my argument. For instance, if Norwegians of Pakistani descent were part of a national consensus in favor of the proposed policy, why would some of these persons at a later time find it insulting to continue carrying it out? However, an important fact about the case makes it possible to accept its setup for the sake of argument and still have grounds to reject the intuition that he reports as evidence that the argumentative approach that I take justifies too much. It is that some of the Norwegians of Pakistani descent who would live in Norway when Pakistanis would start to be excluded would not have been members at the time of the policy's determination, but later would be members. Some of them would not have been born at that earlier time, while others would have been children or adults when the policy was put in place but not yet members of Norwegian society. This includes the one hundred thousand people who would be allowed to immigrate under the policy. Are these people to be fully spoken for by the other Norwegians of Pakistani descent whom we are to imagine having been part of a consensus in favor of the policy? Should their say in this case be entirely beholden to what other persons in their national origin group living in Norway agreed to? These questions, which I do not think Wellman or any other liberal theorist can provide an affirmative answer to, arise even if we grant the setup of Wellman's case for the sake of argument. In other words, even if we grant the premise that the persons who agreed to the policy would have no grounds to complain about its expressive significance later on, this does not imply that persons who did not participate in the national dialogue would have no grounds to do so. A policy of excluding further Pakistani immigrants on the basis of their nationality expresses the judgment that Norwegians of Pakistani descent are not valued members of society. The latter have standing, grounded in the principle of equal respect for members, to reject the policy, even if we suppose that the others who agreed to it do not. We can grant the setup of Wellman's case, then, and nonetheless see that the judgment that the policy of excluding Pakistanis after one hundred thousand more have immigrated could violate the principle of equal respect for members, and therefore be morally impermissible on grounds of domestic justice. Hence the "justifies too much" objection against the attempt to show that policies of outright exclusion are morally impermissible on grounds of domestic justice that Wellman has provided does not go through. The argument that I

ethnicity, of course, will be difficult in many real-world cases. Addressing these difficulties would go beyond the bounds of the present article. 
have provided allows us to give a principled response to this objection, even if we grant the terms of Wellman's case. ${ }^{37}$

To anticipate further objections, I will make two additional points of clarification. First, my argument concludes that societies cannot implement discriminatory immigration policies when these policies would also involve discrimination against members. However, this should not be taken to suggest that I regard all restrictions on immigration as morally impermissible. Even the most steadfast proponents of the open borders position generally hold that threats to national security and social order, such as enemies of the state and persons with serious criminal records in their country of origin, may be excluded. Societies are certainly permitted to exclude terrorists or members of criminal organizations like the Mafia to protect their members from these threats, even when some such persons are also members of society. Similarly for policies that exclude persons with highly morbid and contagious diseases whose presence would genuinely and significantly threaten public safety, even if these diseases afflict some members of society. ${ }^{38}$ The attitudes naturally interpreted as lying behind such policies need not express disrespect for any members of society. Of course, we may have reason to be skeptical of the legitimacy of particular uses of these criteria, for instance if a country used them to exclude only persons from a particular ethnic group or religion. Merely cosmetic attempts to hide discriminatory intentions

37 An anonymous reviewer has raised the issue of whether, rather than blanket exclusion after a certain number have entered, Norway could introduce an annual quota to control the rate of migration from Pakistan in order to support immigration integration. On my view, if the sincere goal of this policy is to help Pakistanis integrate into Norwegian society, and that goal cannot be accomplished equally well in some other way, such a policy would not in any obvious way express disrespect for Norwegians of Pakistani descent. Indeed, it would partly be designed to help them, as integration benefits both immigrants and the receiving society. Of course, the policy's goal must be genuine and not a cover for discriminatory attitudes, as the National Origins Formula in the United States had been and was abolished under the Immigration and Nationality Act of 1965, Pub. L. No. 89-236, 79 Stat. 911 (1965), also known as the Hart-Celler Act, largely on that basis. For a detailed discussion of this transitional period in American immigration law, see Joppke, Selecting by Origin, ch. 2. I am grateful to the reviewer for raising this point.

38 In addition to permitting these grounds for exclusion, which even open borders advocates allow, certain forms of preferred treatment in favor of particular groups can be permissible on my view. For instance, it is plausible that a society may give a preferred immigration status to persons who have been victims of injustices that it has perpetrated without expressing the attitude that any members of society are less than equal to one another. This is perhaps part of justification for the Orderly Departure Program, created in 1979 under the United Nations High Commissioner for Refugees, which involved the United States taking the lion's share of Vietnamese refugees after the Vietnam War. I am grateful to two anonymous reviewers for urging me to clarify these points. 
are not significantly different from policies that involve upfront discrimination morally. These policies would still violate the principle of equal respect for members, whereas policies genuinely grounded in realistic concerns for national security or social order would not. ${ }^{39}$

Second, my argument is compatible with a plausible commitment to responsibilities of immigrants to integrate into the receiving country's political culture in various ways. ${ }^{40}$ Indeed, it is compatible with the view that reasonable adjustment is required both of immigrants and members of the receiving society. This may have been another confounding factor in Wellman's case, where it is presumed that the Norwegians of Pakistani origin must not be allowed to increase their numbers by more than one hundred thousand or else difficult social and political issues might arise. If this were a genuine worry, we might wonder whether members of that community were doing their part to integrate into Norwegian society. If they were not, some immigration policy that would reflect this problem could be justified, but it is far from clear that exclusion of all persons of Pakistani origin would be the morally and practically preferred choice. It is even further from the truth, as far as I can tell, that Norwegians would regard this example as realistic. Indeed, Norway is one of the countries most committed to equality and nondiscrimination, and Pakistani-Norwegians are well-integrated on the whole. Generous immigration policies of societies like Norway are testament to their commitments to these values and the possibility of mutual adjustment in a world in which movement is often necessary. The challenges we face in advancing together as fellow members of liberal societies should be surmounted by policies and approaches that are consonant with our own principles. Exclusion or less than equal treatment on the basis of race, ethnicity, nationality, religion, gender, gender identity, sexual orientation, or disability would conflict with the principles that we strive to secure in the name of liberal values.

Moreover, even if one accepts my argument against the state sovereignty view, one might wonder whether external relationships that involve identification and the principle of equal respect for members have further implications for the ethics of immigration. If someone is inclined to regard any restrictions on entry as impermissible, aside from restrictions that are genuinely required to maintain national security or social order, of course these considerations will not add much more than additional reasons against restrictive policies. However,

As Sarah Fine points out, the long history of racial and ethnic criteria being used in the immigration policies of liberal democracies may mean that employing skill-based or other types of criteria in contemporary societies in particular ways will be morally problematic. See Fine, "Immigration and Discrimination."

See Miller, "Immigrants, Nations, and Citizenship," for an account of these responsibilities. 
I do think that cases can be given where a moderate position would regard certain policies as permissible to implement when only the claims of nonmembers are in view, but impermissible once the argument from disrespect for members is added. Consider a policy of excluding immigrants who have disabilities that would be costly to accommodate in terms of healthcare resources. On the face of it, it may seem reasonable for societies to appeal to the cost of taking certain groups of immigrants in when deciding whom to admit. The policy involves appeal to excessive costs rather than exclusion simply on the basis of having a disability, where the latter may seem morally impermissible to us but the former is not obviously so. When we consider the fact that there are already persons in the society with disabilities that involve similar medical costs to the projected costs that would be used to justify exclusion, the moral situation arguably changes. This is because the policy expresses the attitude that members with these disabilities are a burden on society, contributing less than they receive. Indeed, the Canadian immigration policy of using an excessive demand clause to exclude nonmembers with costly disabilities has been opposed, and I think rightly, by the Council of Canadians with Disabilities partly on the grounds of these kinds of considerations. ${ }^{41}$ It may be reasonable for societies to consider costs in terms of societal resources when setting their immigration policies, but excluding persons with costly disabilities expresses disrespect for members, and is not the only way of managing these costs. It is arguably also the case that policies that would exclude immigrants on the basis of lacking financial resources might be permissible, even if ungenerous, when only the claims of outsiders are taken into account, but impermissible in virtue of expressing disrespect for poor persons within society. ${ }^{42}$ For similar reasons, it may be impermissible to exclude certain immigrants on the basis of age, for instance in skilled-worker admissions. ${ }^{43}$

Immigration and Refugee Protection Act, 2001 S.C., ch. 27, s. 38 (c). The Council of Canadians with Disabilities has stated that "the current law devalues Canadians with disabilities and does nothing to recognize the contribution persons with disabilities and their families can and do make to Canadian society." "Immigration," accessed August 30, 2014, http:// www.ccdonline.ca/en/socialpolicy/immigration. Joseph Carens holds that this sort of policy is not unjust if, contrary to his own considered view, states are morally entitled to control their borders. See Carens, The Ethics of Immigration, 179. With regard to the use of skill-based criteria in immigration, Ayelet Shachar raises important questions about the risks that the use of skill as a qualification for acquiring citizenship may pose to the stability of political equality and shared notions of societal belonging among citizens. See Shachar, "Selecting By Merit."

43 Of course, in the case of spousal reunification, policies that set lower limits on age can be morally permissible and need not express disrespect for any members of society. Such policies may have the legitimate aim of protecting people who would be brought in as underage brides. However, the Danish Immigration Service’s “24-year rule," which set the age restric- 
Such policies are typically justified in terms of long-term productivity but have been opposed on the grounds that they involve problematic age discrimination against members of society. ${ }^{44}$ I cannot discuss these cases at length here, but they suggest paths that can be explored with the argumentative resources used in this article that go beyond the argument against the state sovereignty view.

Additionally, the option of embracing the view that disrespect for even one member is morally significant is compelling, I hold, in thinking through the implications of equal respect for members. To build on the previous example involving disability, there being only one member of society with a costly disability makes the difference between the policy being morally impermissible and being morally permissible to implement, all else being equal. It may be worse in general to discriminate against larger numbers of members than smaller numbers, but the moral difference between zero and one disabled member of society, for instance, is greater here than the difference between forty-nine and fifty. If we take equal respect for members seriously, then this requires that policies not express disrespect for any members unless there is a very significant moral reason to do so. It would be hard to make the case that the only way of managing the potential costs of allowing nonmembers in is to exclude nonmembers with costly disabilities outright. Again, I must leave the details of this sort of proposal for further work. Still, it is an important consequence that disrespect for even one member of society would be this significant, which should be explored outside of the argument against the state sovereignty view.

\section{CONCLUSION}

I argued in this article that the state sovereignty view in the contemporary ethics of immigration literature is unsatisfactory. This view grants societies wide

tion for spousal reunification at twenty-four in Denmark, has come under sharp criticism on the basis that it expresses discriminatory attitudes toward Muslims and is ineffective in achieving its stated purpose of protecting women in forced marriages. As I noted above, the use of age and other criteria can violate the principle of equal respect for members when they are used as a cover for discriminatory attitudes toward particular social groups. I am grateful to an anonymous reviewer for encouraging me to consider the permissibility of different uses of age as a criterion in immigration policy.

The Australian organization сота (formerly the Council on the Ageing), which is intended to represent elderly Australians, has opposed the use of fifty years of age as a cutoff for skilled worker migrants on the grounds that it conflicts with the Age Discrimination Act of 2004, even though the act itself treats migration as an exempt category. See Bolton, "How Old Is Too Old to Become a Migrant?" Opponents of this age restriction also note that similar restrictions are not used in the United States or the European Union. See Biggs, Fredvang, and Haapala, "Not in Australia." 
latitude in determining and implementing their immigration policies. The arguments that Walzer and Wellman provide in defense of the state sovereignty view both rely on the premise that the rights of members generally trump the rights of nonmembers in matters of immigration policy. Yet even if we grant them this premise for the sake of argument, it does not follow that societies can refuse or prefer nonmembers at their discretion. If members of a society are parties to external relationships involving identification with nonmembers on the basis of a shared race, ethnicity, nationality, religion, gender, gender identity, sexual orientation, or disability, immigration policies that discriminate against nonmembers on the basis of these qualities may express disrespect for members. Hence societies are greatly constrained by the demands of domestic justice when setting their immigration policies on grounds that are internal to the state sovereignty view, and the view is internally inconsistent. After giving this argument, I discussed and responded to objections that Wellman has raised against the argumentative approach that I take, anticipated further objections, and suggested additional implications of the approach that would go beyond the argument against the state sovereignty view. In the absence of further objections, it seems that we should put aside the state sovereignty view when attempting to determine what types of immigration policies are and are not morally permissible for societies to implement. ${ }^{45}$

\author{
Brooklyn College, CUNY \\ Australian National University \\ matthew.lindauer@anu.edu.au
}

\title{
REFERENCES
}

Abizadeh, Arash. "Democratic Theory and Border Coercion: No Right to Unilaterally Control Your Own Borders." Political Theory 36 , no. 1 (2008): 37-65.

45 Earlier versions of this paper were presented at the Moral, Social, and Political Theory (МSрт) Seminar at the Australian National University and the Yale Works in Progress Seminar. For comments and discussion, I would like to thank Ray Briggs, Joe Carens, Eric Guindon, Ten-Herng Lai, Holly Lawford-Smith, Christian List, Mark Maxwell, Gerhard Øverland, Jason Stanley, and Ken Winkler. For written comments, I am especially grateful to Christian Barry, Pam Corcoran, Steve Darwall, Luara Ferracioli, Zoltán Gendler Szabó, Shelly Kagan, Serene Khader, Josh Knobe, Seth Lazar, Chris Lebron, Shmuel Nili, Sara Protasi, Daniel Putnam, Julian Reid, Barbara Sattler, Sun-Joo Shin, Jiewuh Song, Laura Valentini, Yuan Yuan, and two anonymous reviewers for this journal. 
Anderson, Elizabeth S. “What Is the Point of Equality?” Ethics 109, no. 2 (January 1999): 287-337.

Appiah, Kwame Anthony. The Ethics of Identity. Princeton: Princeton University Press, 2004.

Barry, Christian, and Gerhard Øverland. "Do Democratic Societies Have a Right to Do Wrong?" Journal of Social Philosophy 42, no. 2 (Summer 2011): 111-31.

Biggs, Simon, Marthe Fredvang, and Irja Haapala. "Not in Australia: Migration, Work, and Age Discrimination." Australasian Journal on Ageing 32, no. 2 (June 2013): 125-29.

Blake, Michael. "Immigration." In A Companion to Applied Ethics, edited by R. G. Frey and Christopher Heath Wellman, 224-37. Malden, MA: Blackwell Publishing, 2003.

- "Immigration, Association, and Antidiscrimination." Ethics 122, no. 4 (July 2012): 748-62.

- "Immigration, Jurisdiction, and Exclusion." Philosophy and Public Affairs 41, no. 2 (Spring 2013): 103-30.

Bolton, Andrew. "How Old Is Too Old to Become a Migrant?" sBs World News Australia Radio. October 24, 2012. Updated August 26, 2013. http://www.sbs. com.au/news/article/2012/10/24/how-old-too-old-become-migrant.

Carens, Joseph H. "Aliens and Citizens: The Case for Open Borders." Review of Politics 49, no. 2 (Spring 1987): 251-73.

. The Ethics of Immigration. New York: Oxford University Press, 2013.

Cavallero, Eric. "Association and Asylum." Philosophical Studies 169, no. 1 (May 2014): 133-41.

Cole, Phillip, and Christopher Heath Wellman. Debating the Ethics of Immigration: Is There a Right to Exclude? New York: Oxford University Press, 2011.

Darwall, Stephen L. “Two Kinds of Respect." Ethics 88, no. 1 (October 1977): 36-49.

Dummett, Michael. On Immigration and Refugees. London: Routledge, 2001.

Dworkin, Ronald. Taking Rights Seriously. Cambridge, MA: Harvard University Press, 1977.

Ferracioli, Luara. "Family Migration Schemes and Liberal Neutrality: A Dilemma." Journal of Moral Philosophy 13, no. 5 (2016): 553-75.

Fine, Sarah. "Freedom of Association Is Not the Answer." Ethics 120, no. 2 (January 2010): $338-56$.

- . "Immigration and Discrimination." In Migration in Political Theory: The Ethics of Movement and Membership, edited by Sarah Fine and Lea Ypi, 12550. Oxford: Oxford University Press, 2016. 
Joppke, Christian. Selecting by Origin: Ethnic Migration and the Liberal State. Cambridge, MA: Harvard University Press, 2005.

Kymlicka, Will. Multicultural Citizenship: A Liberal Theory of Minority Rights. Oxford: Oxford University Press, 1995.

Lister, Matthew. "Immigration, Association, and the Family." Law and Philosophy 29, no. 6 (November 2010): 717-45.

- "A Rawlsian Argument for Extending Family-Based Immigration Benefits to Same-Sex Couples." University of Memphis Law Review 37 (Summer 2007): $745-80$.

Miller, David. "Border Regimes and Human Rights." Law and Ethics of Human Rights 7, no. 1 (August 2013): 1-23.

- "Immigrants, Nations, and Citizenship." Journal of Political Philosophy 16, no. 4 (December 2008): 371-90.

Shachar, Ayelet. "Selecting by Merit: The Brave New World of Stratified Mobility." In Migration in Political Theory: The Ethics of Movement and Membership, edited by Sarah Fine and Lea Ypi, 175-201. Oxford: Oxford University Press, 2016.

Sidgwick, Henry. The Elements of Politics, 2nd ed. London: MacMillan, 1897.

Pevnick, Ryan. Immigration and the Constraints of Justice: Between Open Borders and Absolute Sovereignty. Cambridge: Cambridge University Press, 2011.

Walzer, Michael. Spheres of Justice: A Defense of Pluralism and Equality. New York: Basic, 1983.

- Thinking Politically: Essays in Political Theory. Edited by David Miller. New Haven: Yale University Press, 2007.

Wellman, Christopher Heath. "Immigration and Freedom of Association." Ethics 119, no. 1 (October 2008): 123-32.

Wilcox, Shelley. "Do Duties to Outsiders Entail Open Borders? A Reply to Wellman." Philosophical Studies 169, no. 1 (May 2014): 1-10. 